Correction

\title{
Correction: Goldbeck, R.A., et al. Early Events, Kinetic Intermediates and the Mechanism of Protein Folding in Cytochrome c. Int. J. Mol. Sci. 2009, 10, 1476-1499.
}

\section{Robert A. Goldbeck*, Eefei Chen and David S. Kliger}

Department of Chemistry and Biochemistry, University of California, Santa Cruz, California 95046, USA; E-Mails: chen@chemistry.ucsc.edu (E.C.); kliger@chemistry.ucsc.edu (D.K.)

* Author to whom correspondence should be addressed; E-Mail: goldbeck@chemistry.ucsc.edu; Tel. +1-831-459-4007; Fax: +1-831-459-2935

Received: 16 April 2009 / Published: 17 April 2009

By mistake, we omitted the support from the National Institutes of Health (U.S.A.) in the Acknowledgements section in our paper recently published in Int. J. Mol. Sci. [1]. Therefore, the Acknowledgements section is revised as follows:

\section{Acknowledgements}

The preparation of this article and the authors' folding studies described therein were supported by National Institutes of Health grant EB02056.

\section{References}

1. Goldbeck, R.A.; Chen, E.; Kliger, D.S. Early Events, Kinetic Intermediates and the Mechanism of Protein Folding in Cytochrome c. Int. J. Mol. Sci. 2009, 10, 1476-1499.

(C) 2009 by the authors; licensee Molecular Diversity Preservation International, Basel, Switzerland. This article is an open-access article distributed under the terms and conditions of the Creative Commons Attribution license (http://creativecommons.org/licenses/by/3.0/). 